\title{
Serial Imaging of Virus-Associated Necrotizing Disseminated Acute Leukoencephalopathy (VANDAL) in COVID-19
}

\author{
(D). Agarwal, (D). Conway, (D) V. Nguyen, (D). Dogra, (D). Krieger, (DD. Zagzag, (D)A. Lewis, (D). Melmed, (DS. Galetta, and \\ (iD) Jain \\ O. $=$
}

\begin{abstract}
BACKGROUND AND PURPOSE: Various patterns of leukoencephalopathy have been described in coronavirus disease 2019 (COVID19). In this article, we aimed to describe the clinical and imaging features of acute disseminated leukoencephalopathy in critically ill patients with COVID-19 and the imaging evolution during a short-term follow-up.
\end{abstract}

MATERIALS AND METHODS: We identified and reviewed the clinical data, laboratory results, imaging findings, and outcomes for 8 critically ill patients with COVID-19 with acute disseminated leukoencephalopathy.

RESULTS: All patients demonstrated multiple areas of white matter changes in both cerebral hemispheres; $87.5 \%$ (7/8) of patients had a posterior predilection. Four patients (50\%) had short-term follow-up imaging within a median of 17 days after the first MR imaging; they developed brain atrophy, and their white matter lesions evolved into necrotizing cystic cavitations. All (8/8) patients had inflammatory cytokine release syndrome as demonstrated by elevated interleukin-6, D-dimer, lactate dehydrogenase, erythrocyte sedimentation rate, C-reactive protein, and ferritin levels. Most (7/8; 87.5\%) patients were on prolonged ventilator support (median, 44.5 days; interquartile range, 20.5 days). These patients had poor functional outcomes (6/8 [75\%] patients were discharged with $\mathrm{mRS} 5$ ) and high mortality (2/8, 25\%).

CONCLUSIONS: Critically ill patients with COVID-19 can develop acute disseminated leukoencephalopathy that evolves into cystic degeneration of white matter lesions with brain atrophy during a short period, which we dubbed virus-associated necrotizing disseminated acute leukoencephalopathy. This may be the result of COVID-19-related endothelial injury, cytokine storm, or thrombotic microangiopathy.

ABBREVIATIONS: $\mathrm{ADEM}=$ acute disseminated encephalomyelitis; ARDS = acute respiratory distress syndrome; $\mathrm{CRP}=\mathrm{C}$-reactive protein; $\mathrm{COVID-19}=\mathrm{CO}-$ ronavirus disease 2019; ESR = erythrocyte sedimentation rate; GCS = Glasgow Coma Scale; IL-6 = interleukin-6; INR = international normalized ratio; IQR = interquartile range; $\mathrm{LDH}=$ lactate dehydrogenase; PRES = posterior reversible encephalopathy syndrome; SARS-CoV-2 = Severe Acute Respiratory Syndrome coronavirus 2; VANDAL = Virus Associated Necrotizing Disseminated Acute Leukoencephalopathy; WM = white matter

M uch of the focus regarding the global pandemic of coronavirus disease 2019 (COVID-19) has been on the cardiovascular, pulmonary, and hematologic complications. However, neurologic complications have become increasingly recognized sequelae, with associated high morbidity and mortality. ${ }^{1-5}$ Although the current literature is limited regarding neuroimaging findings in patients with COVID-19, ${ }^{6-8}$ there have been recent reports of critically ill patients with leukoencephalopathy with

Received August 11, 2020; accepted after revision September 16.

From the Departments of Neurology (S.A., J.C., A.L., K.M., S.G.), Radiology (V.N., S.D., P.K., R.J.), Pathology (D.Z.), and Neurosurgery (D.Z., A.L., K.M., R.J.), NYU Langone Health, New York, New York.

Please address correspondence to Rajan Jain, MD, NYU School of Medicine, 660 First Ave, 2nd Floor, NY, NY 10016; e-mail: rajan.jain@nyulangone.org; (aCoolAsANeuroRad

- Indicates open access to non-subscribers at www.ajnr.org

Indicates article with online supplemental data.

http://dx.doi.org/10.3174/ajnr.A6898

or without cerebral microhemorrhages. ${ }^{9-14}$ Different radiologic patterns of white matter (WM) injury have been described in critically ill patients with viral infections, including diffuse leukoencephalopathy with microhemorrhages, acute disseminated encephalomyelitis (ADEM), and posterior reversible encephalopathy syndrome (PRES). ${ }^{11,15-20}$ Due to a paucity of neuropathologic data, the pathophysiologic processes responsible for these imaging characteristics are not completely understood. A recent report on postmortem examination of 5 patients with COVID-19 did not reveal evidence of encephalitis or central nervous system vasculitis, but this series lacked neuroimaging. ${ }^{21}$ Another report suggested that the neuropathologic lesions in patients with COVID-19 had features resembling both vascular and demyelinating etiologies, ${ }^{22}$ but this report also lacked neuroimaging data to correlate with the neuropathologic findings.

In this article, we aimed to describe the clinical, laboratory, and functional outcomes of patients with COVID-19 with acute 
disseminated leukoencephalopathy on brain MR imaging, as well as the imaging evolution of these WM lesions. We examined possible underlying mechanisms for these findings.

\section{MATERIALS AND METHODS}

We performed a retrospective chart review of 115 adult patients positive for COVID-19 who underwent brain MR imaging at 3 tertiary care hospital sites of a single academic medical center from March 1, 2020, to May 10, 2020, and found 8 patients with acute disseminated leukoencephalopathy, 4 (50\%) of whom had $>1$ MR imaging, 3/4 (75\%) who had 2, and 1/4 (25\%) who had 3 MR imagings. MR images obtained on a 3T MR imaging scanner included susceptibility-weighted imaging, while those scanned on a $1.5 \mathrm{~T}$ scanner had gradient-echo imaging. Of the 8 patients, 4 patients had imaging performed on both 1.5T and 3T MR imaging scanners. MRIs were evaluated independently by 2 fellowship-trained neuroradiologists (R.J. and V.N.). Imaging data on the pattern of distribution of the WM lesions and microhemorrhages were collected. Follow-up MR imaging studies were evaluated for progression or evolution of WM lesions and evidence of subjective brain atrophy, defined as an interval increase in the prominence of the ventricles and sulcal spaces due to brain volume loss compared with the baseline study.

S.A., S.D., and P.K. reviewed charts and collected the following data: comorbidities, presenting symptoms, time from symptom onset to presentation, vital signs, ventilator days before brain MR imaging, total ventilator days, the total length of hospitalization, treatment received for COVID-19, occurrence of in-house cardiac arrest, Glasgow Coma Scale (GCS) score at MR imaging and 2 weeks post-MR imaging, acute respiratory distress syndrome (ARDS) severity score (calculated as the lowest partial pressure of oxygen/fraction of inspired oxygen ratio while intubated). ${ }^{23}$ Functional outcomes included discharge mRS, discharge disposition, and death. Discharge mRS scores were calculated by trained physical therapists $\leq 5$ days before discharge or determined by a neurology resident (S.A.) on the basis of the clinical notes when not otherwise documented. We collected laboratory variables including admission and nadir platelet count and fibrinogen levels and admission and peak D-dimer, lactate dehydrogenase (LDH), international normalized ratio (INR), erythrocyte sedimentation rate (ESR), C-reactive protein (CRP), interleukin-6 (IL-6), and ferritin levels.

This study was approved by the New York University Grossman School of Medicine Institutional Review Board, which granted a waiver of informed consent (IRB No. i20-00567).

\section{RESULTS}

All 8 patients with MR imaging findings of acute disseminated leukoencephalopathy were men, with a median age of 59.5 years (range, 38-69 years). Demographic and clinical features of individual patients are shown in the Online Supplemental Data. Although 2 patients had no known comorbidities, the remaining 6 had at least 3 comorbidities on admission. All patients presented with respiratory symptoms (fevers, chills, cough, and dyspnea) and had symptoms for a median of 7 days (range, 4-14 days) before presentation to the emergency department. All patients (100\%) were treated with a combination of hydroxychloroquine and azithromycin,
$62.5 \%(5 / 8)$ were also treated with tocilizumab, and $12.5 \%(1 / 8)$ were given lopinavir-ritonavir. Intubation was required for $87.5 \%$ of patients (7/8), and ventilator support was needed for a median of 44.5 days (range, 24-52 days). Of these 7 patients, $42.9 \%(3 / 7)$ had moderate and $42.9 \%(3 / 7)$ had severe ARDS. The peak systolic blood pressure before the first MR imaging ranged from 162 to $240 \mathrm{~mm} \mathrm{Hg}$. In-hospital cardiac arrest occurred in $37.5 \%(3 / 8)$ of patients, all of whom achieved a return of spontaneous circulation. Nearly all $(87.5 \% ; 7 / 8)$ patients developed acute kidney injury, and 62.5\% (5/8) required continuous renal replacement therapy. At the time of the analysis of this study, 25\% (2/8) of patients had died. There were no neuropathologic specimens available for analysis because postmortem examination was not performed.

These patients had cytokine storming as demonstrated by elevated median IL-6 (admission $=31 \mathrm{pg} / \mathrm{mL}$ [interquartile range $(\mathrm{IQR})=15.5 \mathrm{pg} / \mathrm{mL}] ;$ peak $=49 \mathrm{pg} / \mathrm{mL}[\mathrm{IQR}=73.5 \mathrm{pg} / \mathrm{mL}]$; normal IL-6 levels $=\leq 5 \mathrm{pg} / \mathrm{mL}$ ); D-dimer (admission $=2003 \mathrm{ng} / \mathrm{mL}$ $[\mathrm{IQR}=2980 \mathrm{ng} / \mathrm{mL}] ;$ peak $=8645 \mathrm{ng} / \mathrm{mL}[\mathrm{IQR}=4751.25 \mathrm{ng} / \mathrm{mL}) ;$ normal $=$ D-dimer $<230 \mathrm{ng} / \mathrm{mL}$ ); LDH (admission $=492 \mathrm{U} / \mathrm{L}$ $[\mathrm{IQR}=284 \mathrm{U} / \mathrm{L}] ;$ peak $=970.5 \mathrm{U} / \mathrm{L}[\mathrm{IQR}=605.5 \mathrm{U} / \mathrm{L}]$; normal $\mathrm{LDH}$ levels $=84-246 \mathrm{IU} / \mathrm{L}) ; \mathrm{ESR}($ admission $=83 \mathrm{~mm} / \mathrm{h}[\mathrm{IQR}=$ $60.5 \mathrm{~mm} / \mathrm{h}] ;$ peak $=117 \mathrm{~mm} / \mathrm{h}[\mathrm{IQR}=27.75 \mathrm{~mm} / \mathrm{h}] ;$ normal ESR levels $=0-10 \mathrm{~mm} / \mathrm{h}$ ); CRP (admission $=113.5 \mathrm{mg} / \mathrm{L}[\mathrm{IQR}=$ $106.43 \mathrm{mg} / \mathrm{L}]$; peak = $336 \mathrm{mg} / \mathrm{L}$ [IQR $77.63 \mathrm{mg} / \mathrm{L}]$; normal CFP levels $=0.0-3.0 \mathrm{mg} / \mathrm{L}$ ); and ferritin (admission $=1070 \mathrm{ng} / \mathrm{mL}[\mathrm{IQR}=$ $906.7 \mathrm{ng} / \mathrm{mL}] ;$ peak $=4701.5 \mathrm{ng} / \mathrm{mL}[\mathrm{IQR}=11616.3 \mathrm{ng} / \mathrm{mL}]$; normal ferritin levels $=8.0-388.0 \mathrm{ng} / \mathrm{mL}$ ) (Online Supplemental Data).

Initial neuroimaging with brain $\mathrm{MR}$ imaging was performed at a median of 23.5 days (IQR $=5$ days) since admission and, if intubated, 23 days (IQR $=6.5$ days) after intubation. The indication for neuroimaging was persistent encephalopathy in nearly all $(87.5 \% ; 7 / 8)$ patients. Patients had a median GCS of 5 (IQR = 5.8) on the day of MR imaging, and there was no change in median GCS scores 2 weeks post-MR imaging. These patients had poor functional outcomes ( $75 \%$ of patients with discharge mRS of 5) and a high mortality rate (25\%).

Neuroimaging showed multiple patchy areas of WM restricted diffusion/cytotoxic edema in both cerebral hemispheres, with a predilection for the posterior and subcortical regions in $87.5 \%$ (7/8) of patients. One of the 2 patients who received gadolinium demonstrated enhancement of the WM lesions suggesting BBB breakdown and evidence of central necrosis (Fig 1). Patchy lesions similar to WM lesions were also seen in the cerebellum (62.5\%), brain stem (50\%), and basal ganglia (25\%) (Online Supplemental Data). Most (75\%) patients also had microhemorrhages (Fig 1). Four patients underwent a follow-up MR imaging at a median of 35.5 days (IQR $=14.3$ days) since admission and 17 days ( $\mathrm{IQR}=19.5$ days) after the first MR imaging. Follow-up imaging in all 4 patients showed necrosis and development of small cystic cavitations in the WM lesions (which showed restricted diffusion/cytotoxic edema on the baseline study) and brain volume loss (Online Supplemental Data and Fig 2). Three patients also showed progression of WM lesions, which became more confluent (Fig 3). One patient who had $3 \mathrm{MR}$ imaging studies showed sequential progression of the above WM findings on both follow-up studies. 


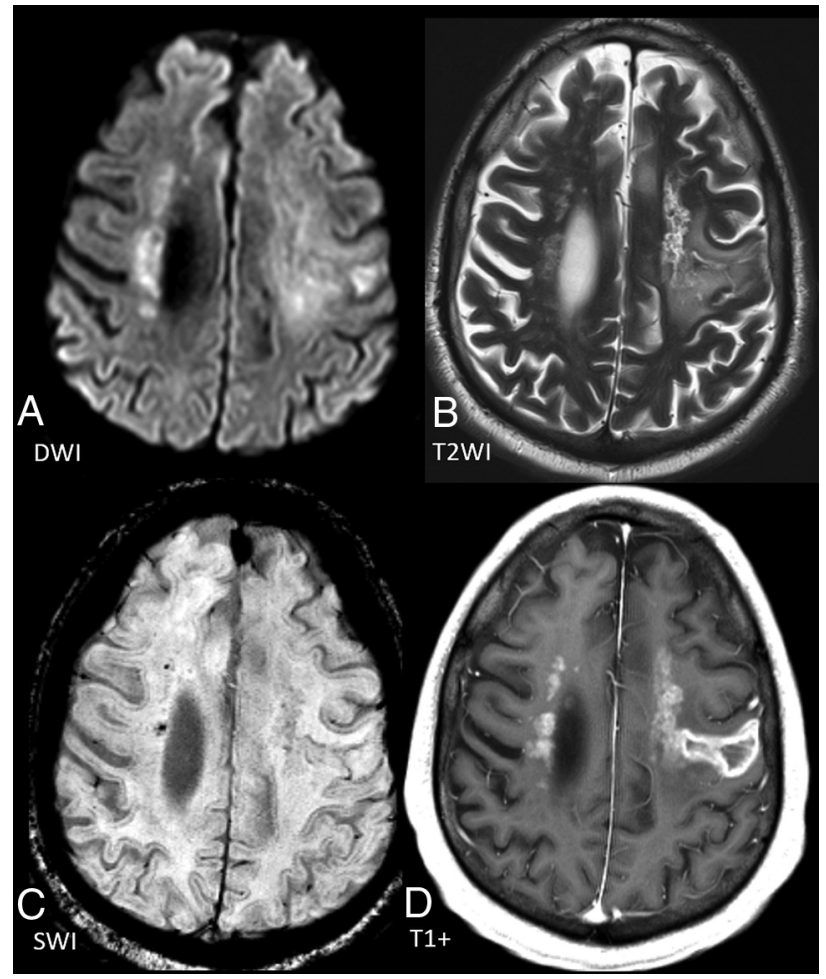

FIG 1. Axial DWI $(A)$ and T2-weighted imaging (B) showing disseminated leukoencephalopathy with associated microhemorrhages (C) seen on the susceptibility-weighted imaging. D, Postcontrast T7weighted imaging shows patchy enhancement of most WM lesions, with the larger lesion in the left cerebral hemisphere also showing central nonenhancement, suggestive of breakdown of the BBB and WM necrosis.

\section{DISCUSSION}

We identified 8 critically ill patients with COVID-19 with acute disseminated leukoencephalopathy. This is the first study, to our knowledge, to show imaging evolution of acute disseminated leukoencephalopathy in patients with COVID-19. All patients who underwent follow-up imaging showed necrosis and cavitation of initial WM cytotoxic lesions as well as brain atrophy during their hospital stay within a fairly short follow-up period. Our findings suggest that this necrotizing leukoencephalopathy leads to rather rapid progression of extensive and permanent white matter damage and brain atrophy in these critically ill patients, which correlate very well with the poor functional outcomes shown in these patients.

Most (87.5\%) of our patients had lesions that were predominantly posterior, similar to lesions seen in PRES. There have been reports of PRES in COVID-19, ${ }^{24,25}$ and while the MRI findings for our patients appear similar to those in PRES, they differ from those in PRES in that these WM changes are more patchy and deep, rather than confluent ${ }^{26}$ and progress rather than resolve on follow-up imaging.

Furthermore, while these lesions bear some similarity to other white matter lesions seen in patients with viral infections, such as acute necrotizing encephalitis ${ }^{27,28}$ or ADEM,,${ }^{29,30}$ they differ from these entities, as well. The WM lesions seen in patients in our study showed multiple diffuse confluent areas of T2/FLAIR hyperintensity, with diffusion restriction suggesting cytotoxic

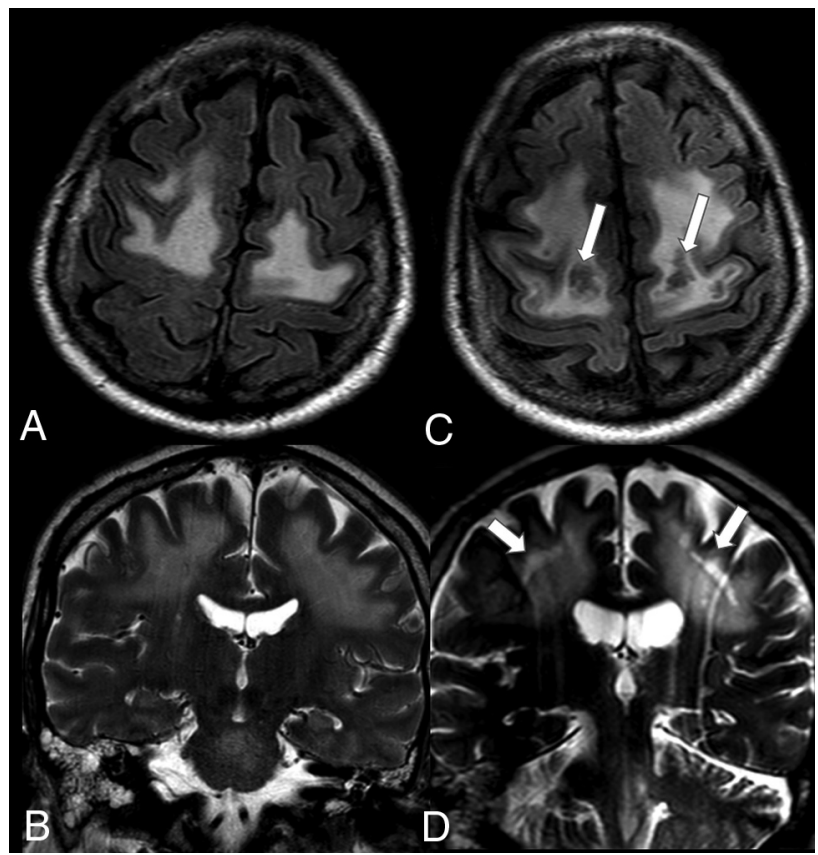

FIG 2. $A$ and $B$, Axial FLAIR and coronal T2-weighted images at baseline MR imaging (day 25) showing multiple confluent areas of leukoencephalopathy. $C$ and $D$, These lesions progressed to show development of cystic cavitations in the WM (arrows) as well as interval prominence of the lateral and third ventricles, suggesting brain atrophy on follow-up MR imaging on day 75 .

edema, which appears to be different from ADEM, in which these lesions are seen more often in subcortical regions with surrounding vasogenic edema. Thus, it appears that these lesions represent a previously undescribed finding, which we have dubbed virusassociated acute necrotizing disseminated leukoencephalopathy, or VANDAL, for short.

There have been serial brain MR imaging studies among critically ill patients without COVID-19 that have demonstrated global brain atrophy with preferential involvement of the superior frontal gyri, thalami, cerebellum, and hippocampal regions. The 4 patients in our study who had follow-up imaging showed brain atrophy. Although there have been no prior studies in patients with COVID-19 with serial imaging showing any evidence of brain atrophy, the findings seen in our patients could be due to either critical illness, hypoxic injury, or cytokine storming. ${ }^{31-33}$

Variable direct and indirect mechanisms of CNS injury due to COVID-19 could be responsible for these imaging findings.

\section{COVID-19-Related Endothelial Injury}

Viral infections have been noted to cause endothelial damage leading to increased permeability of the $\mathrm{BBB} .{ }^{15}$ Some pathologic studies in patients with COVID-19 have shown direct viral invasion of endothelial cells and diffuse endothelial inflammation, ${ }^{34}$ but more recent literature has suggested that these particles may have been misinterpreted as coronavirus and instead represent the rough endoplasmic reticulum. ${ }^{35}$ Severe Acute Respiratory Syndrome coronavirus 2 (SARS$\mathrm{CoV}-2$ ) binds directly to angiotensin-converting enzyme 2 receptors, which can cause weakening of the endothelial layer, 


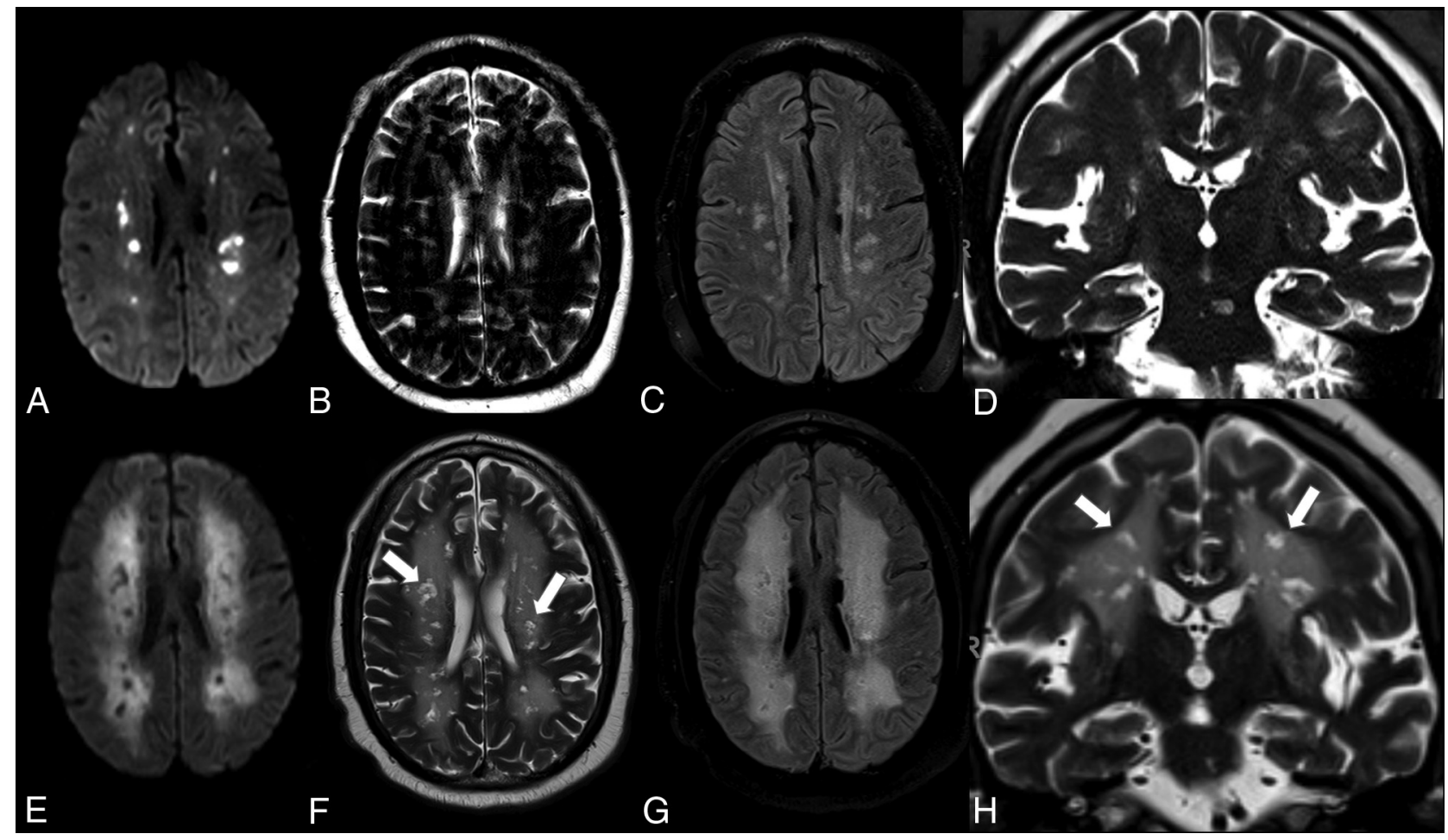

FIG 3. Axial DWI, T2-weighted, FLAIR ( $A-C$ ), and coronal T2-weighted images $(D)$ at baseline MR imaging (day 10) showing multiple patchy areas of restricted diffusion/cytotoxic edema in the WM. E-H, Axial corresponding follow-up MR imaging (day 75) demonstrates development of cystic cavitations in the previous patchy cytotoxic WM lesions (arrows) as well as interval prominence of the lateral and third ventricles, suggesting brain atrophy. Follow-up MR imaging also showed marked progression of more confluent WM lesions surrounding the patchy cystic lesions.

leading to a breakdown of the BBB and subsequent dysfunction of autoregulation. ${ }^{36,37}$ Additionally, SARS-CoV-2 could lead to inflammation of the endothelial lining due to the recruitment of immune cells or hypoxic injury. ${ }^{38}$

PRES has been associated with endothelial dysfunction. ${ }^{39}$ In PRES, peak systolic blood pressure usually is between 170 and $190 \mathrm{~mm} \mathrm{Hg}$, but $10 \%-30 \%$ of patients have normal or only mildly elevated blood pressure. ${ }^{40,41}$ The peak systolic blood pressures in our patients ranged from 162 to $240 \mathrm{~mm} \mathrm{Hg}$. Thus, the imaging changes in our patients may be related to PRES, despite the absence of prolonged hypertension. While PRES usually resolves with time, 4 of our patients who had follow-up imaging were found to have progression of their WM lesions, suggesting that while this process may be related to PRES, it is different. Some of these deep, patchy WM lesions were present in the middle cerebral artery-posterior cerebral artery overlap area and could represent watershed ischemia due to hypoperfusion resulting from hypotension during cardiac arrest (experienced by 37.5\% [3/8] of our patients) or hypotension secondary to sepsis. However, the posterior predominance of these lesions and the presence of lesions in the brain stem and cerebellum, areas not typically associated with watershed ischemia, make this mechanism of injury less likely.

\section{Cytokine Storm}

Patients with COVID-19 who are critically ill have a massive inflammatory reaction believed to be due to accumulation of $\mathrm{T}$ cells and macrophages, resulting in the release of a large number of cytokines into the bloodstream aiming to destroy the offending pathogen and resulting in numerous clinical manifestations known commonly as cytokine release syndrome. ${ }^{42,43}$ Classic laboratory findings of cytokine release include decreased T-cells and natural killer cells and, most important, an increase in IL-6, which leads to fever and multiorgan dysfunction. Higher levels of cytokines and interleukins have been postulated to be related to findings of disseminated leukoencephalopathy in patients with septic shock. ${ }^{44}$ These patients had laboratory evidence of cytokine storming, which could lead to BBB breakdown, promoting the development of acute disseminated leukoencephalopathy.

\section{Thrombotic Microangiopathy}

Microhemorrhages in the subcortical WM and corpus callosum have been reported in high-altitude exposure and ARDS, ${ }^{45}$ and they are believed to be the result of disseminated intravascular coagulation. Microhemorrhages within afflicted posterior and subcortical WM may also be seen in PRES. ${ }^{26,46}$ In the population of critically ill patients with COVID-19, neuroimaging findings of diffuse leukoencephalopathy may be seen in conjunction with microhemorrhages, as is seen in some of our patients. ${ }^{7,10,11,47}$ The appearance of cotton wool spots and microhemorrhages on fundus examinations further suggests pathologic and ophthalmologic evidence of thrombotic microangiopathy in patients with COVID-19. ${ }^{48}$

Thus, endothelial dysfunction, cytokine storming, and thrombotic microangiopathy may contribute to the development of the acute disseminated leukoencephalopathy seen in 
patients with severe COVID-19 described herein. Of course, these factors could also lead to leukoencephalopathy with a variety of other imaging phenotypes. Acute disseminated necrotizing leukoencephalopathy appears to be a harbinger of poor outcome in patients with severe COVID-19, but it is unclear how patients with acute disseminated necrotizing leukoencephalopathy will compare with patients with other COVID-19-asscoiated WM changes during a long period.

Limitations of the current report include a small sample size, retrospective data collection, and a lack of histopathologic data. Nevertheless, there have been other neuropathologic studies published recently that support our findings and provide insight into the neurotropism of SARS-COV $-2^{49}$ and the potential parainfectious processes affecting the neural tissue in COVID-19. ${ }^{22}$ Further neuropathologic studies that include clinical and imaging data are needed to better understand these findings.

\section{CONCLUSIONS}

Critically ill patients with COVID-19 may develop extensive and disseminated leukoencephalopathy, which evolves into cystic/cavitatory necrotizing lesions during a short time period with brain atrophy, correlating with the poor functional outcome in these patients. We believe that these lesions occur as a result of endothelial dysfunction, cytokine storming, and thrombotic microangiopathy. Because these findings appear to be inconsistent with any previously described neuropathology, we have dubbed this virus-associated necrotizing disseminated acute leukoencephalopathy (VANDAL). Histopathologic studies as well as long-term follow-up studies are needed to better understand this phenotype of leukoencephalopathy and determine if and how this is different from other WM changes in patients with COVID-19.

Disclosures: Ariane Lewis_UNRELATED: Expert Testimony; Other: Deputy Editor for Neurology and Seminars in Neurology. Steven Galetta-UNRELATED: Consultancy: Genentech, Biogen. Rajan Jain-UNRELATED: Consultancy: Cancer Panels; Royalties: Thieme.

\section{REFERENCES}

1. Bridwell R, Long B, Gottlieb M. Neurologic complications of COVID19. Am J Emerg Med 2020;38:1549.e3-49.e7 CrossRef Medline

2. Ahmad I, Rathore FA. Neurological manifestations and complications of COVID-19: a literature review. J Neurol Sci 2020;77:8-12 CrossRef Medline

3. Carod-Artal FJ. Neurological complications of coronavirus and COVID-19. Rev Neurol 2020;70:311-22 CrossRef Medline

4. Helms J, Kremer S, Merdji H, et al. Neurologic features in severe SARS-CoV-2 infection. N Engl J Med 2020;382:2268-70 CrossRef Medline

5. Mao L, Jin H, Wang M, et al. Neurologic manifestations of hospitalized patients with coronavirus disease 2019 in Wuhan, China. JAMA Neurol 2020;77:683-90 CrossRef Medline

6. Nicholson P, Alshafai L, Krings T. Neuroimaging findings in patients with COVID-19. AJNR Am J Neuroradiol 2020;41:1380-83 CrossRef Medline

7. Jain R, Young M, Dogra S, et al. COVID-19 related neuroimaging findings: a signal of thromboembolic complications and a strong prognostic marker of poor patient outcome. J Neurol Sci 2020;414: 116923 CrossRef Medline
8. Pons-Escoda A, Naval-Baudín P, Majós C, et al. Neurological involvement in COVID-19: cause or coincidence? A neuroimaging perspective. AJNR Am J Neuroradiol 2020;41:1365 CrossRef Medline

9. Kandemirli SG, Dogan L, Sarikaya ZT, et al. Brain MRI findings in patients in the intensive care unit with COVID-19 infection. Radiology 2020;297:E232-35 CrossRef Medline

10. Agarwal S, Jain R, Dogra S, et al. Cerebral microbleeds and leukoencephalopathy in critically ill patients with COVID-19. Stroke 2020; 51:2649-55 CrossRef Medline

11. Radmanesh A, Derman A, Lui Y, et al. COVID-19 associated diffuse leukoencephalopathy and microhemorrhages. Radiology 2020;297: E223-27 CrossRef Medline

12. Sachs JR, Gibbs KW, Swor DE, et al. COVID-19-associated leukoencephalopathy. Radiology 2020;296:E184- 85 CrossRef Medline

13. Huang H, Eichelberger $H$, Chan $M$, et al. Pearls and oy-sters: leukoencephalopathy in critically ill patients with COVID-19. Neurology 2020 Aug 11 [Epub ahead of print] CrossRef Medline

14. Lang $\mathrm{M}$, Buch $\mathrm{K}, \mathrm{Li} \mathrm{MD}$, et al. Leukoencephalopathy associated with severe COVID-19 infection: sequela of hypoxemia? AJNR Am J Neuroradiol 2020;41:1641-45 CrossRef Medline

15. Claveau JS, LeBlanc R, Ahmad I, et al. Cerebral adenovirus endotheliitis presenting as posterior reversible encephalopathy syndrome after allogeneic stem cell transplantation. Bone Marrow Transplant 2017;52:1457-59 CrossRef Medline

16. Ogunneye O, Hernandez-Montfort JA, Ogunneye Y, et al. Parainfluenza virus infection associated with posterior reversible encephalopathy syndrome: a case report. J Med Case Rep 2012;6:89 CrossRef Medline

17. Muco E, Hasa A, Rroji A, et al. Posterior reversible encephalopathy syndrome in a patient with hemorrhagic fever with renal syndrome. Case Rep Infect Dis 2020;2020:1017689 CrossRef Medline

18. Sasson SC, Oon A, Chagantri J, et al. Posterior reversible encephalopathy syndrome (PRES) in an HIV-1 infected patient with disseminated varicella zoster virus: a case report. BMC Infect Dis 2013; 13:396 CrossRef Medline

19. Bartynski WS, Boardman JF, Zeigler ZR, et al. Posterior reversible encephalopathy syndrome in infection, sepsis, and shock. AJNR Am J Neuroradiol 2006;27:2179-90 Medline

20. Poyiadji N, Shahin G, Noujaim D, et al. COVID-19-associated acute hemorrhagic necrotizing encephalopathy: CT and MRI features. Radiology 2020;296:E119-20 CrossRef Medline

21. Schaller T, Hirschbuhl K, Burkhardt K, et al. Postmortem examination of patients with COVID-19. JAMA 2020;323:2518 CrossRef Medline

22. Reichard RR, Kashani KB, Boire NA, et al. Neuropathology of COVID-19: a spectrum of vascular and acute disseminated encephalomyelitis (ADEM)-like pathology. Acta Neuropathol 2020;140: 1-6 CrossRef Medline

23. Ranieri VM, Rubenfeld GD, Thompson BT, et al; ARDS Definition Task Force. Acute respiratory distress syndrome: the Berlin definition. JAMA 2012;307:2526-33 CrossRef Medline

24. Rogg J, Baker A, Tung G. Posterior reversible encephalopathy syndrome: a manifestation of COVID-19 cytokine storm. Interdiscip Neurosurg 2020;22:100808 CrossRef Medline

25. Kishfy L, Casasola M, Banankhah P, et al. Posterior reversible encephalopathy syndrome (PRES) as a neurological association in severe Covid-19. J Neurol Sci 2020;414:116943 CrossRef Medline

26. McKinney AM, Sarikaya B, Gustafson C, et al. Detection of microhemorrhage in posterior reversible encephalopathy syndrome using susceptibility-weighted imaging. AJNR Am J Neuroradiol 2012;33: 896-903 CrossRef Medline

27. Ormitti F, Ventura E, Summa A, et al. Acute necrotizing encephalopathy in a child during the 2009 influenza $A(H 1 N 1)$ pandemia: MR imaging in diagnosis and follow-up. AJNR Am J Neuroradiol 2010;31:396-400.CrossRef Medline

28. Wong AM, Simon EM, Zimmerman RA, et al. Acute necrotizing encephalopathy of childhood: correlation of MR findings and clinical outcome. AJNR Am J Neuroradiol 2006;27:1919-23 Medline 
29. Rossi A. Imaging of acute disseminated encephalomyelitis. Neuroimaging Clin N Am 2008;18:149-61ix CrossRef Medline

30. Honkaniemi J, Dastidar P, Kahara V, et al. Delayed MR imaging changes in acute disseminated encephalomyelitis. AJNR Am J Neuroradiol 2001;22:1117-24 Medline

31. Herridge MS, Moss M, Hough CL, et al. Recovery and outcomes after the acute respiratory distress syndrome (ARDS) in patients and their family caregivers. Intensive Care Med 2016;42:725-38 CrossRef Medline

32. Garbade SF, Boy N, Heringer J, et al. Age-related changes and reference values of bicaudate ratio and sagittal brainstem diameters on MRI. Neuropediatrics 2018;49:269-75 CrossRef Medline

33. Hopkins RO, Suchyta MR, Beene K, et al. Critical illness acquired brain injury: Neuroimaging and implications for rehabilitation. Rehabil Psychol 2016;61:151-64 CrossRef Medline

34. Varga Z, Flammer AJ, Steiger P, et al. Endothelial cell infection and endotheliitis in COVID-19. Lancet 2020;395:1417-18 CrossRef Medline

35. Goldsmith CS, Miller SE, Martines RB, et al. Electron microscopy of SARS-CoV-2: a challenging task. Lancet 2020;395:e99 CrossRef Medline

36. $\mathrm{Wu} \mathrm{Y,} \mathrm{Xu} \mathrm{X,} \mathrm{Chen} \mathrm{Z,} \mathrm{et} \mathrm{al.} \mathrm{Nervous} \mathrm{system} \mathrm{involvement} \mathrm{after} \mathrm{infec-}$ tion with COVID-19 and other coronaviruses. Brain Behav Immun 2020;87:18-22 CrossRef Medline

37. Baig AM, Khaleeq A, Ali U, et al. Evidence of the COVID-19 virus targeting the CNS: tissue distribution, host-virus interaction, and proposed neurotropic mechanisms. ACS Chem Neurosci 2020;11: 995-98 CrossRef Medline

38. Teuwen LA, Geldhof V, Pasut A, et al. COVID-19: the vasculature unleashed. Nat Rev Immunol 2020;20:389-91 CrossRef Medline

39. Marra A, Vargas M, Striano P, et al. Posterior reversible encephalopathy syndrome: the endothelial hypotheses. Med Hypotheses 2014; 82:619-22 CrossRef Medline
40. Fugate JE, Claassen DO, Cloft HJ, et al. Posterior reversible encephalopathy syndrome: associated clinical and radiologic findings. Mayo Clin Proc 2010;85:427-32 CrossRef Medline

41. Roth C, Ferbert A. The posterior reversible encephalopathy syndrome: what's certain, what's new? Pract Neurol 2011;11:136-44 CrossRef Medline

42. Xie J, Tong Z, Guan X, et al. Clinical characteristics of patients who died of coronavirus disease 2019 in China. JAMA Netw Open 2020;3:e205619 CrossRef Medline

43. Mehta P, McAuley DF, Brown M, et al; HLH Across Speciality Collaboration, UK. COVID-19: consider cytokine storm syndromes and immunosuppression. Lancet 2020;395:1033-34 CrossRef Medline

44. Sharshar T, Gray F, Poron F, et al. Multifocal necrotizing leukoencephalopathy in septic shock. Crit Care Med 2002;30:2371-75 CrossRef Medline

45. Fanou EM, Coutinho JM, Shannon P, et al. Critical illness-associated cerebral microbleeds. Stroke 2017;48:1085-87 CrossRef Medline

46. Hefzy HM, Bartynski WS, Boardman JF, et al. Hemorrhage in posterior reversible encephalopathy syndrome: imaging and clinical features. AJNR Am J Neuroradiol 2009;30:1371-79 CrossRef Medline

47. Breit H, Jhaveri M, John S. Concomitant delayed posthypoxic leukoencephalopathy and critical illness microbleeds. Neurol Clin Pract 2018;8:e31-33 CrossRef Medline

48. Marinho PM, Marcos AA, Roman AC, et al. Retinal findings in patients with COVID-19. Lancet 2020;395:590-92 CrossRef Medline

49. Puelles VG, Lütgehetmann M, Lindenmeyer MT, et al. Multiorgan and renal tropism of SARS-CoV-2. N Engl J Med 2020;383:590-92 CrossRef Medline

50. Radmanesh A, Derman A, Ishida K. COVID-10-associated delayed posthypoxic necrotizing leukoencephalopathy. J Neurol Sci 2020; 415:116945 CrossRef Medline 